and meiotic course. Khoshoo ${ }^{8}$ has also reported a similar situation in Sisymbrium irio, in which meiotic disturbances were caused by summer heat.

A detailed account of these investigations will be published elsewhere.

I am indebted to the principal of this College, Dr. A. N. Banerji, for providing the necessary facilities in connexion with the present investigations.

\section{P. Malik}

Department of Botany,

Deshbandhu College,

University of Delhi, New Delhi 19.

1 Darlington, C. D., and Wylie, A. P., "Chromosome Atlas of Flowering Plants" (George Allen and Unwin, Ltd., London, 1955).

${ }^{2}$ Malik, C. P., and Sehgal, S. M., J. Sci. Indust. Res., 18, c, 155 (1959).

${ }^{3}$ Sax, Karl, Amer. J. Bot., 24, 218 (1937).

${ }^{4}$ Gustafsson, A., and Nygren, A., Hereditas, 32, 1 (1946).

${ }^{5}$ Matsuura, $\mathrm{H}$, and Haga, T., Cytologia, 10, $382(1940)$.

6 Malik, C. P., and Tandon, S. L., Ind. J. Hort., 16, 39 (1959).

'Malik, C. P., and Tandon, S. L., J. Sci. Indust. Res., 18, c, 233 (1959).

${ }^{8}$ Khoshoo, T. N., Caryologia, 11, 297 (1959).

\section{Race Differences in the Ability to excrete Beetroot Pigment (Betanin)}

IT has been suggested that lack of betanin excretion in urine is a hereditary trait in $\operatorname{man}^{1}$. This could result from an inborn incapacity to metabolize the pigment. This communication reports a study of the frequencies of betanin excretors among different racial groups. Classification of the excretors necessitated taking into account the time-range necessary for excretion, the amount of beetroot eaten and the $p \mathbf{H}$ of the urine. The effect of these variables on the validity of the test was determined before establishing the following procedure. 100-150 gm. of cooked beetroot was given to each individual examined. Two test-tube samples were taken, one before and the other $5 \mathrm{hr}$. after the beetroot was eaten. The classification of the individuals as excretors and nonexcretors was based on visual comparison of the colour of the two urine samples. When any reddish tint could be observed in the second sample relative to the first the subject was recorded as 'excretor', and if otherwise, 'non-excretor'. It should be noted that a great deal of variation was observed in the intensity of the red tint in the urine of the excretors.

As betanin is a $p \mathrm{H}$ indicator, the possibility that a high $p H$ in the urine could suppress the appearance of the colour was checked. It was found that lowering the $p \mathrm{H}$ near 5 in the urine of the 'non-excretor' group failed to reveal any reddish tint. On the other hand, an increase of $p \mathrm{H}$ to 8 in the 'excretor' group was needed to make the tint fade. Since human urine has a $p \mathrm{H}$ varying between $4 \cdot 8$ and $8 \cdot 2$ (average, 6 ) it can be concluded that the $p \mathrm{H}$ value of the urine does not appreciably affect the results.

It was observed that betanin elimination by the adult excretors occurs 4-11 hr. after eating beetroot, the most intense concentration of the pigment in urine being about 5-6 hr. after ingestion. Among children 8-14 years old, the corresponding time is 3-4 hr.

A group of 338 individuals from São Paulo was examined in State schools for resident pupils, where the tests could be controlled. The investigation includes 181 Japanese of age-range between 7 and 24 years, 50 Negroes 'pure' and 'mixed' of age-range
Table 1

\begin{tabular}{|l|c|c|c|c|}
\hline & Sample & Mean age & $\begin{array}{c}\text { No. of individuals } \\
\text { examined }\end{array}$ & \multicolumn{2}{|c|}{$\begin{array}{c}\text { Excretors } \\
\text { No. }\end{array}$} & Per cent \\
\hline Japanese & $14 \cdot 6$ & 181 & 80 & $44 \cdot 2$ \\
Negro & $31 \cdot 9$ & 50 & 16 & $32 \cdot 0$ \\
White & $23 \cdot 9$ & 107 & 33 & $30 \cdot 8$ \\
Total & $19 \cdot 4$ & 338 & 129 & $38 \cdot 2$ \\
\hline
\end{tabular}

Heterogeneity, $\chi^{2}(2)=6 \cdot 13, P<0.05$.

between 20 and 46 years and 107 Whites of age-range between 13 and 53 years. The frequencies of excretors in the three samples are given in Table 1.

It should be noted that the frequencies of excretors among two different samples of Japanese taken at random were $47 \cdot 6$ per cent $(n=103)$ and $45 \cdot 3$ per cent $(n=64)$. The frequency of excretors among Whites from São Paulo, who came from different European immigrant groups, is higher than that observed for the English group (10 per cent) ${ }^{1}$. This fact is likely to be caused by the heterogeneous origin of our White sample (mainly of Italian and Portuguese derivation) and/or by differences in technique. The difference in frequencies of excretors between the White and the Negro samples $\left(\chi_{(1)}^{2}=0.02, P>\right.$ 0.90 ), or between the Negro and the Japanese samples $\left(\chi^{2}(1)=2 \cdot 40, P=0.12\right)$ is not significant. However, the difference in frequencies of excretors between the White and the Japanese samples $\left(\chi_{1}^{2}(1)=5 \cdot 03\right.$, $P=0.025)$ is significant. The overall frequencies of excretors among male (4l.1 per cent) and female (36.1 per cent) individuals are not significantly different $\left(\chi^{2}{ }_{(1)}=0.52, P=0.53\right)$. A group of 40 individuals of the Japanese sample has been investigated previously for taste thresholds for phenylthiourea ${ }^{2}$, but the two traits showed no association $\left(\chi_{(1)}^{2}=2 \cdot 43, P=0 \cdot 12\right)$.

The samples from the three ethnic groups investigated have different average ages. If betanin excretion changes with the age of the individual, this perhaps could explain the differences found. However, classifying the individuals according to the overall mean age (about $20 \mathrm{yr}$.) the results given in Table 2 were obtained.

Table 2

\begin{tabular}{|l|l|c|c|}
\hline \multicolumn{1}{|c|}{ Sample } & Age group & $\begin{array}{c}\text { No. of } \\
\text { individuals }\end{array}$ & $\begin{array}{c}\text { Excretors } \\
\text { (per cent) }\end{array}$ \\
\hline Japanese & below 20 yr. & 158 & $44 \cdot 3$ \\
White & 20 yr. and over & 23 & $43 \cdot 5$ \\
& below 20 yr. & 34 & $26 \cdot 5$ \\
& 20 yr. and over & 73 & $32 \cdot 9$ \\
\hline
\end{tabular}

Hence, it can be seen that age variation cannot account for the differences found. Therefore, our results suggest marked differences in the frequency of betanin excretors among racial groups. Studies of this trait in other populations should be of interest.

\section{P. H. Saldoanha \\ L. E. Magalhĩes \\ WANDA A. HoRTa}

Laboratório de Genética Humana, Faculdade de Medicina, and

Departamento de Biologia Geral, Universidade de São Paulo, Brazil.

'Allison, A. C., and McWhirter, K.G., Nature, 178, 748 (1956). 2 Saldanha, P. H., Ann. Hum. Genet., 22, 380 (1958). 